\title{
Optimum Mix for Pervious Geopolymer Concrete (GEOCRETE) Based on Water Permeability and Compressive Strength
}

\author{
Salaheddin Abdulsalam Arafa ${ }^{1}$, Ahmad Zurisman Mohd Ali ${ }^{1,{ }^{*}}$, Siti Nazahiyah Rahmat ${ }^{2}$, and \\ Yee Loon Lee ${ }^{3}$ \\ ${ }^{1}$ Jamilus Research Centre, Universiti Tun Hussein Onn Malaysia, 86400, Batu Pahat, Johor, Malaysia \\ ${ }^{2}$ Faculty of Civil and Environmental Engineering, Universiti Tun Hussein Onn Malaysia, 86400, Batu \\ Pahat, Johor, Malaysia \\ ${ }^{3}$ Faculty of Civil and Environmental Engineering, International Institute of Cambodia, Sangkat Chak \\ Angre Krom, Khan Mean Chey, Phnom Penh, Cambodia
}

\begin{abstract}
The production of ordinary Portland cement (OPC) consumes considerable natural resources and energy, and it also affects the emission of a significant quantity of $\mathrm{CO}_{2}$ in the atmosphere. This pervious geopolymer concrete study aims to explore an alternative binder without OPC. Pervious geopolymer concretes were prepared from fly ash (FA), sodium silicate $\left(\mathrm{NaSiO}_{3}\right)$, sodium hydroxide $(\mathrm{NaOH})$ solution, and coarse aggregate (CA). The effects of pervious geopolymer concrete parameters that affect water permeability and compressive strength are evaluated. The FA to CA ratios of 1:6, 1:7,1:8, and 1:9 by weight, CA sizes of 5-10, 1014 , and 14-20 mm, constant $\mathrm{NaSiO}_{3} / \mathrm{NaOH}$ ratio of 2.5 , alkaline liquid to fly ash (AL/FA) ratios of $0.4,0.5$, and 0.6 , and $\mathrm{NaOH}$ concentrations of 8 , 10 , and $12 \mathrm{M}$ were the pervious geopolymer concrete mix proportions. The curing temperature of $80^{\circ} \mathrm{C}$ for $24 h$ was used. The results showed that a pervious geopolymer concrete with $\mathrm{CA}$ of $10 \mathrm{~mm}$ achieved water permeability of $2.3 \mathrm{~cm} / \mathrm{s}$ and compressive strength of $20 \mathrm{MPa}$ with $\mathrm{AL} / \mathrm{FA}$ ratio of $0.5, \mathrm{NaOH}$ concentration of $10 \mathrm{M}$, and FA:CA of 1:7. GEOCRETE is indicated to have better engineering properties than does pervious concrete that is made of ordinary Portland cement.
\end{abstract}

\section{Introduction}

Concrete is the most used construction material worldwide, and ordinary Portland cement (OPC) is one of its most essential components. At present, Portland cement is an important material for manufacturing concrete. Concrete production fulfills the global demand of over 1.5 billion tons annually. The production of Portland cement releases a significant volume of carbon dioxide $\left(\mathrm{CO}_{2}\right)$ to the atmosphere, and it is also energy intensive $[1,2]$. For each ton of synthetic Portland cement, one ton of $\mathrm{CO}_{2}$ is estimated to be emitted into the environment. The process embraces high temperatures $\left(1400-1500{ }^{\circ} \mathrm{C}\right)$ and quarry

\footnotetext{
*Corresponding author: zurisman@uthm.edu.my
} 
demolition to extract raw materials, and the process causes the release of greenhouse gases such as $\mathrm{CO}_{2}$ [3]. The costs related with these energy requirements are significant. Thus, further investigation is needed.

In addition to the necessity of large land area for the fly ash disposal, the use of OPC as the primary binder in every building construction is also a well-known environmental issue. Given the continuous growth of construction development, the use of cement materials in construction works is also increasing directly. This condition will increase the demand of OPC production throughout the world. This rising demand contributes roughly $7 \%$ of the total greenhouse gas emissions to the atmosphere [2]. Indirectly, this situation causes global warming that negatively affects the planet. Therefore, alternatives must be established to reduce OPC production.

Readily available commercial by-products, such as blast furnace slag and fly ash, have been adopted to meet these demands. By the 2010, roughly 780 billion tons of fly ash were produced [4]. Recycling will improve disposal and concrete manufacturing costs. A considerable electrical power supply is needed for various uses because of modern population growth and rapid development. One of the major sources of power generation is from thermal power plant (TPP). The by-products from these power plants typically contain a fine material type called fly ash and a coarse material type called bottom ash. Disposal of fly ash is a primary problem and requires considerable land area. As the cost and land requirement are increasing, these by-products should be reused for another purpose.

Davidovits [5] proposed that aluminum $(\mathrm{Al})$ and silicon $(\mathrm{Si})$ react with alkaline liquid from a geological source or by-product materials, such as rice husk ash and fly ash, to produce paste. Polymerization process is the chemical reaction referred to in this study, and the term geopolymer is used to describe the paste production. The production of geopolymer concrete does not use Portland cement.

Geopolymer is a type of inorganic polymer that is produced by the reaction of aluminosilicate materials with alkaline liquid [6]. Geopolymer has shown many excellent properties, such as good resistance against acid and sulfate attacks, high early strength, and good performance in high temperature [7-9]. Geopolymer does not use cement, and it reduces the emission of greenhouse gas by $44-64 \%$. Furthermore, certain wastes and byproducts, such as blast furnace slag and fly ash, are appropriate sources of aluminosilicate, which are used to produce geopolymer. Given that geopolymers are made from by-product materials, they have lower environmental impact in comparison to other types of concrete binders $[10,11]$.

The rapid growth of development has caused the imbalance of the storm water management in Malaysia. As natural areas are build up over urbanization storm, water runoff flow and volumes are significantly increased. These conditions are caused by the increase of impermeable land cover and decreased frequency of flooding that occurs downstream of the urban drainage system as well as the increased potential for stream bank erosion because of high flow velocities. Thus, the water quality is degraded in general and contributes to drastic changes in streambeds. The large percentage of impervious surface is noted to contribute to another form of pollution [12].

In this study, the main purpose is to design a concrete that allows water to pass through it (pervious concrete). Besides that, pervious concrete can be used as temporary storage for raining water and pavement. This type of pavement can reduce the skid resistance and provides safety to the users.

Compared to normal concrete, the pervious concrete is a special concrete that contains voids and possesses high water permeability. It has been developed as an environment friendly material that is used in permeable pavement, water purification, thermal insulation, acoustic absorption, and other applications in civil engineering and architecture [13, 14]. Generally, the void content is between $15 \%$ and $35 \%$ with sizes of connected pore in 
pervious concrete that ranges from $2 \mathrm{~mm}$ to $8 \mathrm{~mm}$ in diameter, and the compressive strength is between $2.8 \mathrm{MPa}$ and $28.0 \mathrm{MPa}$. The high porosity is attained by highly interconnected void content. High void content of pervious concrete allow water to drain naturally in the range of $\mathrm{L} / \mathrm{min} / \mathrm{m}^{2} 81$ to $730 \mathrm{~L} / \mathrm{min} / \mathrm{m}^{2}$, and this can remove the normal surface-water drainage infrastructure, reduce the runoff from a site, and allow ground water recharge when conventional concrete does not [15]. It can be used in the pedestrian walkways, park areas, tennis courts, greenhouses, areas with light traffic, and other civil engineering and architectural works $[15,16]$. Typically, pervious concrete consists of CA, binder, and admixture. Generally, the binding material that is used in pervious concrete is Portland cement, and further investigation on the use of other binding materials, such as geopolymer binders, in pervious concrete is still needed.

Therefore, this study focuses on the use of a fly ash as a source material, sodium silicate and sodium hydroxide solution as an alkaline solution, and CA for making pervious geopolymer concrete. The water permeability and compressive strength of the pervious geopolymer concrete were tested. The obtained data will undoubtedly be beneficial for the future use of fly ash geopolymer in the construction of pervious concrete. Thus, this will lead to the reduction of cement consumption and environmental problems.

\section{Properties of materials used}

The raw materials for pervious geopolymer concrete mixes are sodium hydroxide, sodium silicates (as alkaline solution), CA, and FA. Fly ash was collected from the Sejingkat power plant in Kuching Sarawak. The chemical composition of fly ash was determined with the use of X-ray (XRD) $\left(\mathrm{SiO}_{2}=55.7 \%, \mathrm{AL}_{2} \mathrm{O}_{3}=24.22 \%, \mathrm{Fe}_{2} \mathrm{O}_{3}=9.1 \%, \mathrm{~K}_{2} \mathrm{O}=4.42 \%, \mathrm{CaO}=\right.$ $2.45 \%, \mathrm{MgO}=1.36 \%, \mathrm{TiO}_{2}=1.33 \%$, and less than $1 \%$ for $\mathrm{P}_{2} \mathrm{O}_{5}, \mathrm{BaO}, \mathrm{Na}_{2} \mathrm{O}$, and $\mathrm{MnO}$ ). Sodium silicate and sodium hydroxide were used as combination of alkaline solution. Sodium hydroxide in pelts forms with $98 \%$ purity. This agent was used and purchased from the local chemical supplier, and sodium silicate solution $\left(\mathrm{Na}_{2} \mathrm{O}=16.84 \%, \mathrm{SiO}_{2}=35.01 \%\right.$, and water $=46.37 \%$ by mass) was used as alkaline liquid. Dissolving the pelts in water is prepared with sodium hydroxide solution. Tap water that is available in the laboratory was used to prepare the sodium hydroxide solution. The alkaline solution was prepared at least one day before use. Three sizes of CA ranging from either $5 \mathrm{~mm}$ to $10 \mathrm{~mm}, 10 \mathrm{~mm}$ to 14 $\mathrm{mm}$, or $14 \mathrm{~mm}$ to $20 \mathrm{~mm}$ were used in geopolymer pervious concrete mixes. The specific gravity of the natural aggregate was 2.63 . The water absorption of the natural aggregate was $2.76 \%$ in saturated surface, and a dry condition was used for making pervious geopolymer concrete.

\section{Experimental program}

The prepare geopolymer concrete mixtures were grouped into four, namely, M1, M2, M3, and M4. M1 group of mixtures was prepared to study the influence of aggregate content on pervious geopolymer concrete properties. M2 group of mixtures was prepared to study the influence of aggregate size on pervious geopolymer concrete properties. M3 group of mixtures was prepared to study the influence of the ratio of alkaline liquid to fly ash (AL/FA) on pervious geopolymer concrete properties. M4 group of mixtures was prepared to study the influence of sodium hydroxide solution concentration on pervious geopolymer concrete properties. An optimum proportion of aggregate content was obtained. Thus, the influences of other parameters were studied by making M2, M3, and M4 groups of mixtures. 


\section{Mix proportions, mixing, and casting}

The optimum pervious geopolymer concrete mix was determined by casting pervious geopolymer concrete cubes in order to obtain the optimum ratios of FA/CA, size of CA, ratio of AL/FA, sodium hydroxide concentration (Molarity) based on compressive strength, and water permeability. Pervious geopolymer concrete was made with FA/CA ratio (1:6, $1: 7,1: 7.5,1: 8$, and 1:9), the sizes of CA $(5-10,10-14$, and 14-20 mm. AL/FA ratio (0.4, 0.5 , and 0.6 ), and sodium hydroxide concentration $(8,10$, and $12 \mathrm{M})$. The $\mathrm{NaSIO}_{3} / \mathrm{NaOH}$ ratio was kept constant at 2.5 and cured for $24 \mathrm{~h}$ at $80{ }^{\circ} \mathrm{C}$ in an oven. The pervious geopolymer concrete mixing was done in a $25^{\circ} \mathrm{C}$ controlled room. FA was mixed with alkaline liquid for $5 \mathrm{~min}$ in a pan-type mixer. CA was then incorporated and mixed for another minute. After being mixed, the pervious geopolymer concrete was molded in 100x100x100 mm cubes. The specimens were wrapped with a thin plastic sheet to minimize moisture loss before being cured for $24 \mathrm{~h}$ at $80^{\circ} \mathrm{C}$ in an oven.

\section{Testing detail}

\subsection{Compressive strength}

All specimens casted in 100x100x100 mm cubes were molded and tested after $24 \mathrm{~h}$ by using a $250 \mathrm{KN}$ capacity loading machine in displacement control at a rate of $1 \mathrm{~mm} / \mathrm{min}$ until failure [17]. The mean value obtained from the 3 cubes was taken as the cube compressive strength for each pervious geopolymer concrete mix. The compressive strength of pervious geopolymer concrete is calculated by dividing the maximum load attained from the test by the cross-sectional area of the cube.

\subsection{Water permeability}

Permeability is an important parameter of pervious concrete because the material is designed to be used as drainage layer in pavement structures. The water permeability coefficient of pervious geopolymer concrete was tested by using the constant head method and carried out when a steady state flow was reached $[18,19]$. The coefficients of water permeability $(\mathrm{k})$ were the three specimen averages, and they were calculated by following Darcy's law as shown in the following Equation (1).

$$
K=\frac{Q}{H}
$$

where $\mathrm{k}$ is the coefficient of water permeability $(\mathrm{cm} / \mathrm{s}), \mathrm{Q}$ is the quantity of water collected $\left(\mathrm{cm}^{3}\right)$ over time $\mathrm{t}(\mathrm{s}), \mathrm{L}$ is the thickness of specimen $(\mathrm{cm}), \mathrm{H}$ is the water head $\left(\mathrm{h}_{2}-\mathrm{h}_{1}\right)(\mathrm{cm})$, and $\mathrm{A}$ is the cross-sectional area of the specimen $\left(\mathrm{cm}^{2}\right)$.

\section{Results and discussions}

\subsection{Effect of fly ash to aggregate ratio on the permeability and strength of pervious geopolymer concrete}

The influence of different FA/CA ratio on the compressive strength $24 \mathrm{~h}$ after the temperature curing period and the water permeability of pervious geopolymer concrete are 
presented in Figure 1. The compressive strength of pervious geopolymer concrete increases with a decrease in aggregate content. For example, the $24 \mathrm{~h}$ compressive strength with FA/CA ratios of $1: 6,1: 7,1: 8$, and 1:9 were $21.6,19.8,10.2$, and $8.7 \mathrm{MPa}$, respectively. In addition, the significant increase in water permeability with increasing aggregate content could be observed in Fig. 1.

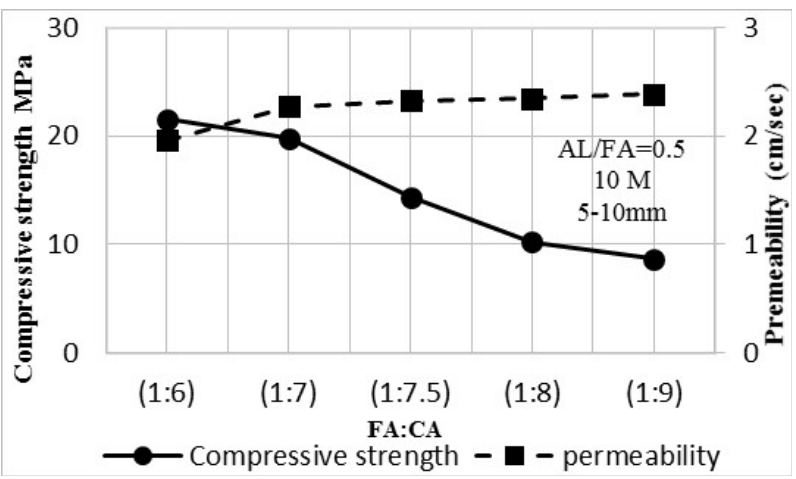

Fig. 1. The relationship between water permeability and compressive strength with different FA/CA percentage.

The optimum aggregate to fly ash ratio is shown in Fig. 1. Water permeability of 2.27 $\mathrm{cm} / \mathrm{s}$ and compressive strength of $19.8 \mathrm{MPa}$ were obtained, and the optimum with 1:7 aggregate to fly ash ratio was also achieved.

\subsection{Effect of aggregate size on strength and permeability of pervious geopolymer concrete}

Fig. 2 shows the influence of different aggregate size on the water permeability and compressive strength of pervious geopolymer concrete. The bulk density of aggregate is decreased with the increase in the aggregate size, and this in turn increased the porosity of the concrete. Mahboub et al. (2009) [20] reported that the porosity of pervious concrete can be estimated with the knowledge of the bulk density of the aggregate via the existing linear relationship.

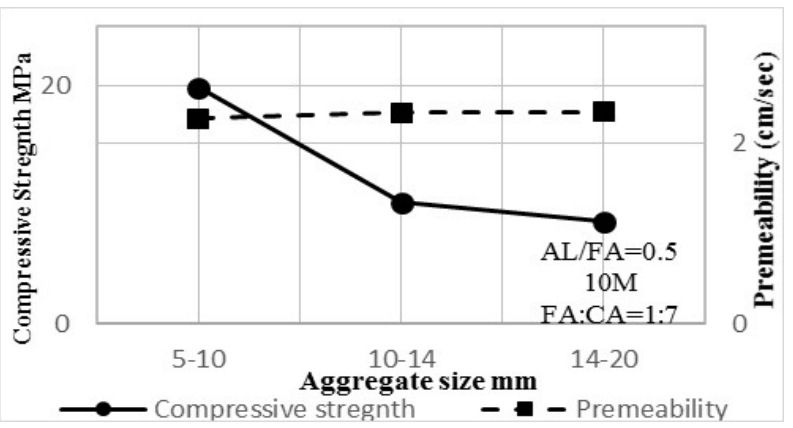

Fig. 2. The relationship between water permeability and compressive strength with different Aggregate sizes 
The strength of pervious concrete decreases with the increase in the porosity. The variation in the permeability with water head is observed for pervious concrete with different aggregate sizes. The highest permeability of pervious geopolymer concrete with $14-20 \mathrm{~mm}$ aggregate size was $2.35 \mathrm{~cm} / \mathrm{s}$. The highest permeability had the highest porosity. The lowest permeability of $2.26 \mathrm{~cm} / \mathrm{s}$ with the pervious geopolymer concrete with $5-10$ $\mathrm{mm}$ aggregate size was recorded. The lowest permeability had the lowest porosity.

The relationship between compressive strength and permeability for pervious geopolymer concrete as a function of the water head is shown. As expected, the highest water permeability of pervious geopolymer concrete is when the compressive strength is the lowest. The variation in the permeability with water head is observed for pervious concrete with different aggregate sizes.

\subsection{Effect of fly ash to alkaline liquid ratio on strength and permeability of pervious geopolymer concrete}

As shown in Fig. 3, the compressive strength of pervious geopolymer concrete increased slightly with an increase in the AL/FA ratio. At AL/FA ratios of 0.40 , the pervious geopolymer concrete contained low liquid and was difficult to compact. The pervious geopolymer concrete with high void contents and low compressive strengths was obtained. The compressive strengths of 16.4, 19.8, and 18.7 $\mathrm{MPa}$ were obtained for pervious geopolymer concrete with AL/FA ratios of $0.4,0.5$, and 0.6 , respectively. With an AL/FA ratio of up to 0.5 , the compressive strength increases, and beyond that, it decreases. This was consistent with the study conducted by Sathonsaowaphak et al. (2009) [21]. An increase in the compressive strength of the lignite bottom ash geopolymer mortar with the increase in $\mathrm{AL} / \mathrm{FA}$ ratios from 0.325 to 0.429 was noted.

The water permeability coefficients of pervious geopolymer concrete were between 2.86 and $2.10 \mathrm{~cm} / \mathrm{s}$ because of the different void contents. Generally, the water permeability coefficients in this study slightly decreased with increasing AL/FA. For instance, the water permeability coefficients for AL/FA ratios of $0.4,0.5$, and 0.6 were $2.86,2.32$, and 2.10 $\mathrm{cm} / \mathrm{s}$, respectively.

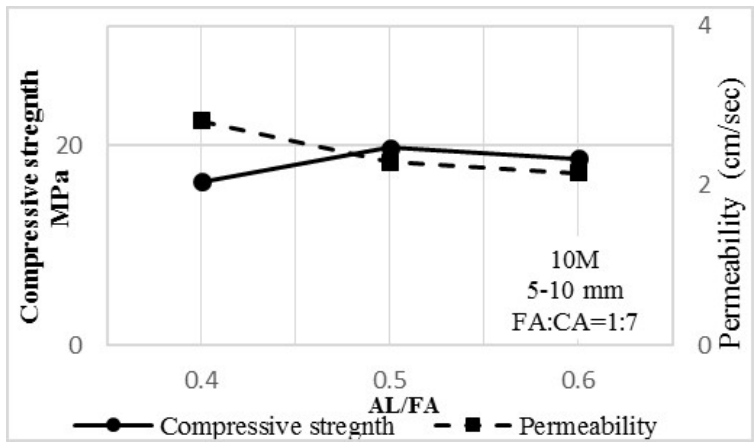

Fig. 3. The relationship between water permeability and compressive strength with different AL/FA ratios

In addition, the significant increase in water permeability with a decrease in the compressive strength is observed as shown in Figure 3. The highest water permeability was $2.86 \mathrm{~cm} / \mathrm{s}$ with the lowest strength of 16.4, and the highest compressive strength was 19.8 MPa with the lowest water permeability of $2.10 \mathrm{~cm} / \mathrm{s}$. These values were obtained from $\mathrm{AL} / \mathrm{FA}$ ratios of $0.4,0$, and 0.5 , respectively. The water permeability increased with a 
decrease in the compressive strength. However, the good relationship between the compressive strength and water permeability was not because of the narrow void content. The addition of alkali liquid in the mixture increased the paste content, and the excess paste filled the voids. Thus, a relatively dense pervious concrete with low void content, low water permeability, and high strength is observed [22].

\subsection{Effect of concentration of sodium hydroxide solution on strength and permeability of pervious geopolymer concrete}

The compressive strength and water permeability of pervious geopolymer concrete with different $\mathrm{NaOH}$ concentrations but the same paste content are shown in Figure 4. The compressive strength of pervious geopolymer concrete that increased with the increase of $\mathrm{NaOH}$ molarity up to a value of 10 is shown in Figure 4, and when $\mathrm{NaOH}$ molarity is further increased, the compressive strength decreases. The optimum $\mathrm{NaOH}$ concentration in producing a good strength of pervious geopolymer concrete of $19.8 \mathrm{MPa}$ was $10 \mathrm{M}$.

The water permeability of the pervious geopolymer concrete with different $\mathrm{NaOH}$ concentrations and the same paste content did not vary. The water permeability of pervious geopolymer concrete that increased with the increase of $\mathrm{NaOH}$ molarity is shown in Figure 4. For instance, the water permeability coefficients for $\mathrm{NaOH}$ concentrations of $8 \mathrm{M}, 10 \mathrm{M}$, and $12 \mathrm{M}$ were $2.21 \mathrm{~cm} / \mathrm{s}, 2.28 \mathrm{~cm} / \mathrm{s}$, and $2.36 \mathrm{~cm} / \mathrm{s}$, respectively. A decreased $\mathrm{NaOH}$ concentration in the mixture increased the paste content, and the excess paste filled the voids. Therefore, a relatively dense pervious concrete with low void content and low permeability is observed.

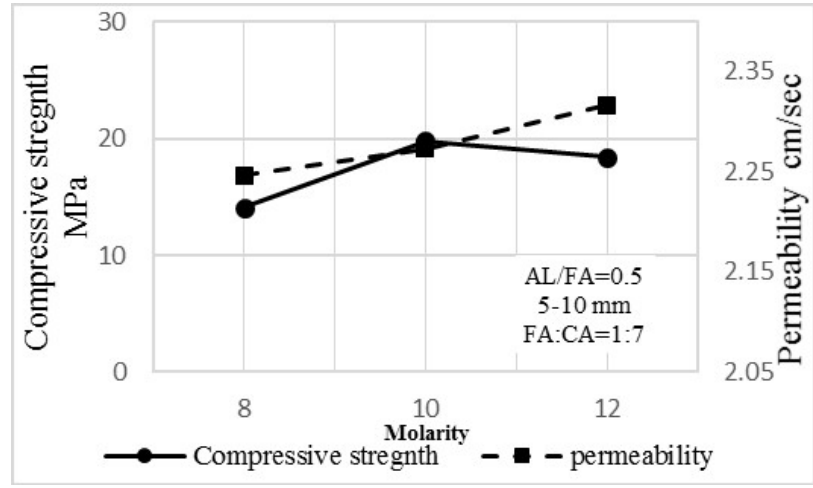

Fig. 4. The relationship between water permeability and compressive strength with different sodium hydroxide concentrations

The increase in water permeability with a decrease in the compressive strength is shown in Figure 4. Water permeability of $2.28 \mathrm{~cm} / \mathrm{s}$ and compressive strength of $19.8 \mathrm{MPa}$ were obtained with an optimum of $10 \mathrm{M}$.

\section{Conclusion}

Based on the compressive strength and water permeability measurement of pervious geopolymer concrete made with class F fly ash, activate alkali, and CA (with different sizes that range from $5 \mathrm{~mm}$ to $20 \mathrm{~mm}$ ), the following conclusions were made: 
i) Compressive strength and water permeability of pervious geopolymer concrete depend primarily on the porosity of the concrete; age, binder material type, FA/CA ratio, and $\mathrm{CA}$ size showed marginal influence on the strength and water permeability of pervious geopolymer concrete.

ii) This study shows the possibility of obtaining the optimum of compressive strength and water permeability from different FA/CA ratios, different sizes of CA, different $\mathrm{AL} / \mathrm{FA}$ activator ratios, and different percentage of sodium hydroxide concentrations for pervious geopolymer concrete mixture.

iii) Reduction in the aggregate size decreased the porosity and water permeability of pervious geopolymer concrete, and thus, the strength of pervious concrete is increased.

iv) The FA/CA ratios had a significant effect on pervious geopolymer concrete properties. The increase in the aggregate portion resulted in the increase of pervious geopolymer concrete's porosity and water permeability. The increase was observed with a decrease in the compressive strength and density of the pervious geopolymer concrete.

v) The compressive strength increased with an increase in sodium hydroxide concentration up to a value of $10 \mathrm{M}$, and when $\mathrm{NaOH}$ is further increased, the compressive strength decreases, and it decreases with an increasing alkaline activator/fly ash ratio. In addition, $\mathrm{NS} / \mathrm{NaOH}$ ratio, $\mathrm{AL} / \mathrm{FA}$ ratio, and $\mathrm{NaOH}$ concentration did not have a significant effect on the water permeability of pervious geopolymer concrete.

vi) Based on the present study, a pervious geopolymer concrete with FA/CA ratio of 1:7, CA of $5-10 \mathrm{~mm}, \mathrm{NaOH}$ molarity of $10, \mathrm{Na}_{2} \mathrm{SiO}_{3} / \mathrm{NaOH}$ ratio of 2.5 , and AL/FL ratio of 0.5 when cured for $24 \mathrm{~h}$ at $80^{\circ} \mathrm{C}$ gave optimum ratios for compressive strength of $19.8 \mathrm{MPa}$ after temperature curing for $24 \mathrm{~h}$ and water permeability of $2.29 \mathrm{~cm} / \mathrm{s}$.

vii) The workability of the pervious geopolymer concrete in fresh state increases with the increase of $\mathrm{AL} / \mathrm{FL}$ ratio, but it decreases with the increasing sodium hydroxide concentration.

This study was supported by Fundamental Research Grant Scheme (FRGS) (Vote 1523).

\section{References}

[1] D. Sumajouw, D. Hardjito, S. Wallah, B. Rangan, Fly ash-based geopolymer concrete: Study of slender reinforced columns, J. of Materials Science, 42(9), 3124-3130 (2007)

[2] J. Davidovits, Geopolymer, green chemistry and sustainable development solutions, Proc. of the World Congress Geopolymer, Geopolymer Institute (2005)

[3] J. Fernandez, M. Ana, A. Palomo, C. Lopez-Hombrados, Engineering properties of alkali-activated fly ash concrete, ACI Materials J., 103(2),106-112 (2006)

[4] D. Khale, R. Chaudhary, Mechanism of geopolymerization and factors influencing its development, J. of Materials Science 42(3), 729-746 (2007)

[5] J. Davidovits, Geopolymer chemistry and properties, Geopolymer, 88, 25-48 (1988)

[6] D. Kong, L. Sanjayan, G. Jay, K. Sagoe-Crentsil, Comparative performance of geopolymers made with metakaolin and fly ash after exposure to elevated temperatures, Cement and Concrete Research, 37(12),1583-1589 (2007)

[7] D. Kong, L. Sanjayan, Damage behavior of geopolymer composites exposed to elevated temperatures, Cement and Concrete Composites, 30(10), 986-991 (2008)

[8] A.Z. Mohd Ali, J. Sanjayan, The spalling of geopolymer high strength concrete wall panels and cylinders under hydrocarbon fire, MATEC Web of Conf, 47, 1-5 (2016) 
[9] A. Awal, M.H. Wan Ibrahim, A.Z. Mohd Ali, M. Zakaria, Mechanical properties and thermal behaviour of two-stage concrete containing palm oil fuel ash, International Journal of Geomate, (2017, in press)

[10] S.N. Rahmat, A.Z. Mohd Ali, M.H. Wan Ibrahim, N.A. Alias, Oil and grease $(\mathrm{O} \& \mathrm{G})$ removal from commercial kitchen waste water using carbonised grass as a key media, The 9th International Unimas Stem Engineering Conference, 87, 01010 (2017)

[11] B. Rangan, B. Vijaya, Concrete construction engineering handbook, $2^{\text {nd }}$ eds., CRC Press, New York, United State (2008)

[12]A. Zakaria, N. Azazi, A. Ghani, R. Abdullah, L. Sidek, H. Kassim, A. Ainan, MSMAA new urban stormwater management manual for Malaysia, The 6th International Conference on Hydro-Science and Engineering (2004)

[13] M. Kevern, T. John, V. Schaefer, K. Wang, Evaluation of pervious concrete workability using gyratory compaction, J. of Materials in Civil Engineering, 21(12), 764-770 (2009)

[14] H. Kim, H. Lee, Acoustic absorption modeling of porous concrete considering the gradation and shape of aggregates and void ratio, J. of Sound and Vibration, 329 (7) 866-879 (2010)

[15] ACI committee 522, Pervious concrete, Report No. 522R-10, American Concrete Institute, Detroit, USA, 38 (2010)

[16]J. Tyner, S. Wright, P. Dobbs, Increasing exfiltration from pervious concrete and temperature monitoring, J. of Environmental Management, 90(8), 2636-2641 (2009)

[17] C 39/C 39M-01, Standard test method for compressive strength of cylindrical concrete specimens, American Society for Testing and Materials, USA (2003)

[18]Japan Concrete Institute, Construction and recent applications of porous concrete, Proc. of the JCI symposium on design, 1-10 (2004)

[19] S. Park, B. Lee, Y. Jang, A study on the seawater purification characteristics of waterpermeable concrete using recycled aggregate, Resour. Conserv. Recy., (54), 658-65 (2010)

[20]K. Mahboub, C. Jonathan, R. Rathbone, T. Robl, B. Davis, Pervious concrete: Compaction and aggregate gradation, ACI Materials J., 106, (6), 523-528 (2009)

[21]A. Sathonsaowaphak, P. Chindaprasirt, K. Pimraksa, Workability and strength of lignite bottom ash geopolymer mortar, J. of Hazardous Materials, 168(1), 44-50 (2009)

[22]P. Chindaprasirt, S. Matakana, T. Chareerat, M. Mishima, Y. Yuasa, Cement paste characteristics and porous concrete properties, Constr. Build. Mater., 22, 894-901 (2008) 